\title{
A Comuna de Paris de 1871 e a atualidade \\ DO SEU INTERNACIONALISMO
}

Sílvio Costa*

silvio.costa.puc.goias@gmail.com

Resumo: A Comuna de Paris de 1871 foi a primeira experiência de governo proletário da história. Mesmo ocorrida há 140 anos, ela continua atual, e seu estudo e conhecimento, associados aos de outras revoluções, contribuem para desnudar conhecidas e velhas falácias do fim da história. A experiência da Comuna de Paris permite ao proletariado compreender que não só é possível, mas um dever fundamental e um direito lutar por seus ideais de liberdade, igualdade e fraternidade que, ainda presentes, constituem a seiva que levará à construção de uma nova sociedade.

Palavras-chave: Comuna de Paris, luta de classes, revolução, poder proletário, feminismo.

A primeira década deste século tem demonstrado, de forma cada vez mais evidente, as contradições e o estertor do projeto civilizatório burguês. A recente crise econômico-financeira que eclode a partir do centro do império, manifesta-se em suas diferentes dimensões e de forma contundente em diversos países. Seja através do processo recessivo, seja por meio do número de desempregados (que atinge diversos países, principalmente os EUA e a União Europeia), ou pelas recentes revoltas que se alastram pelo mundo árabe (Tunísia, Egito, Argélia, Líbia, Bahrein etc.), golpeando mortalmente a era das ditaduras que atingiu diferentes continentes a partir dos anos de 1960-1970.

Nesse contexto, estudar (conhecer com maior profundidade) as experiências revolucionárias - que marcaram o processo de emancipação do proletariado e dos povos oprimidos - assume grande atualidade e urgência. Ao comemorar, em 2011, os 140 anos da tentativa do proletariado de Paris de, segundo Marx, tentar tomar o céu de assalto, nos oportuniza analisar

\footnotetext{
* Professor de Sociologia, Ciência e Teoria Política na Pontifícia Universidade Católica de Goiás (PUC/ GO). Doutorando na Universidad Complutense de Madrid.
} 
criticamente essa primeira experiência de governo proletário na história da humanidade.

Analisando as últimas décadas da História mundial, é possível perceber que não se consolidam as tentativas de implantação do ideário neoliberal, de impor a falácia de que chegamos ao "fim da história", de que a barbárie é sinônima de democracia, liberdade, o objetivo e fim último do desenvolvimento social. Esses mistificadores afirmam não haver alternativas viáveis ao livre mercado, ao "reino" da mercadoria. Mas, em que pesem seu poderio e suas pressões, não encontram campo fértil em importantes parcelas da população que não se submetem às tentativas de imposição da barbárie.

As experiências das revoluções proletárias - qualquer que seja a avaliação sobre seus resultados, seus erros e acertos - nos permitem afirmar que, do ponto de vista da construção de uma sociedade igualitária e fraterna, ainda são revoluções incompletas e apresentam uma série de problemas e debilidades. Isso porque as revoluções não são provocadas por fatores fortuitos, pela vontade subjetiva de alguns líderes, independente do processo histórico real. As revoluções não são fatos produzidos artificialmente, como resultados de desejos individuais; são, sim, produzidas a partir das modificações econômicas, sociais, políticas, culturais que aprofundam as contradições inerentes ao próprio desenvolvimento das sociedades; e, também, quando parcela significativa da população entende que não é mais possível continuar vivendo sob a ordem existente e que é necessário transformá-la.

\section{Os ANTECEDENTES DA INSURREIÇÃO}

Acontecimentos dramáticos antecederam e anunciaram a insurreição parisiense contra o capitulacionismo frente às tropas que ocupavam a França. Essa revolta transformou-se em revolução social, de caráter proletáriopopular. Conhecida como Comuna de Paris de 1871, marcou com heroísmo e sangue o período compreendido entre 18 de março e o desfecho trágico a 28 de maio, quando do massacre dos últimos communards.

Os antecedentes imediatos à deflagração da Comuna de Paris ocorreram a partir de $1^{\circ}$ de setembro de 1870, com a derrota francesa para os prussianos na Batalha de Sedan e prisão de Napoleão III, que havia construído o II Império a partir de 1851, quando do golpe de Estado denominado por Marx o 18 Brumário de Luís Bonaparte. A 4 de setembro, as tropas prussianas iniciaram a ocupação da França e marcharam rumo a Paris. 
Estando o país sem um governo legítimo, foram criadas condições para que a população de Paris desse início a uma insurreição popular e a proclamação da República. Imediatamente, através de hábeis articulações políticas entre republicanos e monarquistas, formou-se um Governo Provisório. Porém, esses acontecimentos não resultaram e não significaram uma vitória das classes populares, muito menos a desestruturação do Estado burguês, posto que o governo provisório foi composto majoritariamente por monarquistas e, em parte, por republicanos conservadores.

A dubiedade e as vacilações do Governo Provisório frente aos invasores permitiram às classes populares pressioná-lo e obrigá-lo a entregar armas à população, o que, nesse momento, significou armar o proletariado. A situação contraditória e o vazio político e militar criaram a necessidade e as condições para que a Guarda Nacional assumisse papel de destaque na organização da resistência. A 19 de setembro de 1870, as tropas prussianas cercaram Paris, enfrentando heroica resistência; não conseguiram ocupá-la.

O Governo negou-se a organizar a resistência, assumindo posições dúbias e capitulacionistas. Entretanto, Paris não aceitou essa capitulação e optou por resistir e lutar, reivindicando eleições e a instalação da Comuna. Porém, essa primeira tentativa insurgente fracassou em decorrência da falta de organização, de decisões rápidas, pela inexistência de lideranças políticas reconhecidas e respeitadas. O Governo conseguiu impor-se, prender cerca de 60 insurgentes e passar à repressão. Contudo, o proletariado não se intimidou, passou a organizar a resistência e, por iniciativa popular, as prisões foram invadidas e libertados os prisioneiros políticos. Frente a necessidades organizativas prementes, iniciou-se a constituição do poder proletário, independente do Governo Provisório que avançava em sua pretensão de capitular às tropas inimigas; nesses embates, lideranças foram surgindo e se afirmando entre as classes trabalhadoras.

As tropas prussianas - ante as divergências entre o governo provisório e o proletariado de Paris e a explicitação aberta da luta de classes propuseram uma trégua, mas estabeleceram condições: a realização imediata de eleições, a formação de uma Assembleia Nacional e de um governo com "legitimidade" para assinar a rendição, o desarmamento da Guarda Nacional e a ocupação dos fortes de Paris pelas tropas invasoras. A Guarda Nacional diante da possiblidade de início de uma guerra civil, para evitá-la, recuou e acatou os termos do armistício, permitindo a entrada de tropas prussianas e a ocupação de parte de Paris. 


\subsection{Eleições como farsa}

As eleições foram realizadas em tempo exíguo e conduzidas de forma profundamente antidemocrática. Associadas ao cerco de Paris, permitiu-se plena liberdade de ação (e as condições foram extremamente favoráveis) aos conservadores e reacionários que desenvolveram volumosa campanha de calúnias contra os republicanos radicais, os socialistas e o proletariado parisiense.

A Assembleia Nacional eleita, composta predominantemente por conservadores, temendo a revolta parisiense, reuniu-se primeiro em Bordeaux e depois em Versalhes, escolhendo Thiers como chefe de governo, com a tarefa de acertar as condições da rendição da França à Prússia.

Os parisienses (que procuravam organizar seu próprio governo) propuseram à Assembleia Nacional e ao Governo em Versalhes uma negociação, fazendo duas reivindicações: autonomia de Paris, com direito de eleger seus representantes e governantes, e a não efetivação da rendição incondicional.

A 10 de março de 1871, não aceitando negociar e em atitude provocativa, a Assembleia Nacional transferiu-se, formalmente, e o Governo para Versalhes. A represália e a intransigência demonstrada provocaram, em contrapartida, o crescimento das ideias revolucionárias e, a cada dia, o proletariado conquistava novos apoios, ampliava seu arsenal e fortalecia a defesa da cidade. Thiers, compreendendo que era chegado o momento de organizar as condições necessárias à ocupação militar de Paris, estabeleceu negociações com Bismarck e conseguiu a libertação de soldados franceses aprisionados durante a guerra.

\section{0 deflagrar da Comuna}

A 18 de março, as tropas sob ordens de Thiers passaram à ofensiva. Ocuparam, na madrugada, as colinas de Montmartre, mas foram surpreendidos por populares que não aceitaram a retirada dos canhões. Ante a irredutibilidade popular, o general comandante das tropas ordenou aos soldados abrirem fogo, por duas vezes, sobre a multidão que não se intimidou. Frente ao impasse, os soldados confraternizaram-se com a população, prenderam e fuzilaram o comandante.

É importante destacar que, apesar do machismo vigente, as mulheres assumiram destacado papel no desenrolar do processo de lutas da Comuna. Foram elas que 
se colocaram à frente da cena, desde o dia 18 de março. Não somente as mulheres eram muito ativas nos clubes, mas criaram o primeiro movimento feminino de massas. [...] Os obstáculos eram numerosos: a "falocracia" milenar e, mais próximo àquele período, o proudhonismo que pregava a manutenção da mulher no lar. Imaginem bem, os próprios eleitos da Comuna eram impregnados pelo machismo, como muitos proudhonianos. Mas é o movimento das mulheres, a ação das mulheres, a democracia direta que levará a Comuna a constituir uma etapa importante na direção da emancipação das mulheres. Dou alguns exemplos: desenvolveu-se a instrução feminina, até então inexistente, inclusive em áreas técnicas; instituiu-se a noção de que "a trabalho igual, corresponde salário igual" - não sei como é no Brasil, mas na França isto está longe de ser realidade até hoje; as concubinas passaram a ter os mesmos direitos das mulheres casadas e os filhos naturais eram considerados iguais em direito aos filhos dos casais legítimos. Na França, foram necessários mais de 120 anos para que se voltasse a obter estatutos semelhantes; aboliuse a prostituição com a exploração comercial de criaturas humanas por outras criaturas humanas. (WILLARD, 2001, p. 19-20)

A partir desse acontecimento, rompida qualquer possibilidade de negociação com o Governo de Versalhes, a Guarda Nacional passou a ocupar Paris.

A revolta contida até aquele momento explodiu com acentuado conteúdo revolucionário, estabelecendo uma luta encarniçada entre dois campos de classes e duas concepções de sociedade: de um lado, o proletariado e diferentes segmentos populares passaram a resistir e a não aceitar a capitulação; ao buscarem conquistar uma República social, pagaram com seu sangue e sua vida a ousadia de tentar tomar o céu de assalto. Por outro lado, os conservadores e reacionários apostaram, através da luta contra Paris, destruir toda e qualquer possibilidade de superação da sociedade de privilégios, baseada na exploração e opressão.

O Comitê Central da Guarda Nacional assumiu o governo de Paris e declarou todos os poderes provisórios, até a realização das eleições para formação do Conselho da Comuna. Porém, com a intenção de evitar a guerra civil (já iniciada), cometeu um grave erro ao não marchar e derrotar Versalhes já no primeiro momento, quando o governo ainda não se encontrava preparado para enfrentar uma guerra contra Paris. Ao contrário, possibilitou a continuidade da ação política dos reacionários, inclusive sua participação no processo eleitoral. 
Na Paris rebelde - mesmo em duras condições de sobrevivência, como fome, desemprego, bombardeios sistemáticos etc. - permitiu-se a mais ampla liberdade e estabeleceu-se um clima de criatividade, solidariedade, congratulações; e a perspectiva de conquista de uma nova sociedade trouxe a felicidade de viver. Essas condições amplamente democráticas permitiram não só o trabalho de construção de relações solidárias, mas também a livre ação para os sabotadores; os jornais monarquistas, inclusive, circularam em Paris, atacando a Comuna e disseminando a perfídia.

Após as eleições, ao assumir o poder, o Conselho da Comuna não conseguiu colocar em funcionamento as instituições político-administrativas herdadas do antigo regime. Isso porque as mesmas, conforme haviam sido organizadas, expressavam o poder do capital sobre o trabalho; na essência, não correspondiam somente à organização de caráter administrativo, mas eram, fundamentalmente, uma máquina voltada para a manutenção do despotismo de classe. Esses fatos demonstraram para os communards tanto a impossibilidade de apoderar-se do antigo aparato estatal para colocá-lo em ação, como a necessidade de novas instituições, de se organizar um novo tipo de Estado.

\subsection{A organização de um novo tipo de Estado}

A primeira iniciativa do Conselho da Comuna foi dissolver o Exército regular, substituindo-o pela Guarda Nacional democrática, ou seja, pelo povo armado. Os acessos às posições de direção e de comando, a exemplo de todos os outros cargos, seriam ocupados através de eleições por voto universal e com mandato imperativo.

O Conselho da Comuna, coordenado por uma Comissão Executiva, possuía atribuições executivas e legislativas, cabendo a ele sancionar as leis e assumir a responsabilidade por sua aplicação. Assim, a implementação das decisões era atribuição dos membros do Conselho da Comuna que divididos em comissões - Exército, Justiça, Segurança Geral, Superior de Contabilidade (finanças), Abastecimento, Instrução Pública, Saúde Pública, Trabalho e Comércio, Relações Exteriores, Serviços Públicos - deviam prestar contas sobre o desempenho das diferentes questões que lhes eram atribuídas (Martorano, 2001, p. 76).

A Magistratura foi reconstituída através de eleições para os cargos nos tribunais civis. Organizavam-se as Cortes de Justiça e eram designados os Juízes de Paz e de Instrução. A assistência jurídica era assegurada gratuitamente para os casos considerados urgentes. A manutenção da ordem 
pública, garantida pela população em armas. O Estado devia ser laico, e a Igreja, enquanto instituição, desvinculada do Estado. Várias igrejas e conventos foram transformados em clubes populares.

A Comuna respeitava a propriedade privada e confiscava apenas as daqueles que haviam deixado Paris. Diversas residências abandonadas eram destinadas, provisoriamente, a vítimas dos bombardeios. A todos aqueles que haviam permanecido na cidade, era garantido o controle de todas suas propriedades e foi concedida a moratória das dívidas.

Segundo Marx,

a Comuna pretendia abolir essa propriedade de classe que converter o trabalho de muitos na riqueza de uns poucos. A Comuna aspirava à expropriação dos expropriadores. Queria fazer da propriedade individual uma realidade, transformando os meios de produção, a terra e o capital, que hoje são fundamentalmente meios de escravização e de exploração do trabalho, em simples instrumentos de trabalho livre e associado. [...] A classe operária não esperava da Comuna nenhum milagre. Os operários não têm nenhuma utopia já pronta para introduzir "par décret du peuple". Sabem que para conseguir sua própria emancipação, e com ela essa forma superior de vida para a qual tende irresistivelmente a sociedade atual, por seu próprio desenvolvimento econômico, terão que enfrentar longas lutas, toda uma série de processos históricos que transformarão as circunstâncias e os homens. Eles não têm que realizar nenhum ideal, mas simplesmente libertar os elementos da nova sociedade que a velha sociedade burguesa agonizante traz em seu seio. (MARx, 1977, p. 203)

O sistema educativo foi reestruturado. O ensino passou a ser também laico e obrigatório, sendo assegurado o caráter científico das várias disciplinas. Instituíram-se escolas profissionais e foi elaborado um plano para a criação de berçários e jardins de infância. Foi fundada a Associação Republicana das Escolas, com o objetivo de estimular o conhecimento científico e a formação política. Ao nível de cultura, surgiu a Federação dos Artistas, reorganizou-se a Academia de Belas Artes e foram estabelecidas escolas comunais de artes. Os teatros e as bibliotecas foram colocados sob o controle das diferentes associações populares.

O exercício das liberdades democráticas foi assegurado indistintamente a todos, inclusive aos simpatizantes de Versalhes; mesmo os prisioneiros e reféns tinham a liberdade para receber visitas e mandar vir de fora sua alimentação, roupas, livros, jornais. A solidariedade e a ideia de humanidade eram colocadas acima das divergências. Foi decretado que toda detenção 
deveria ser precedida de uma ordem judicial e ser comunicada imediatamente ao Delegado da Justiça. Os ultrajes seriam castigados e as pessoas responsáveis, destituídas e submetidas a processo. Eram asseguradas amplas liberdades individuais e de defesa aos acusados e prisioneiros. Proliferavam diferentes organizações populares e sindicais, tanto seções da Internacional, como clubes revolucionários. A representação corporativa dos trabalhadores ficava a cargo das Câmaras Sindicais. As distintas concepções de mundo, identificadas com o proletariado, expressavam-se abertamente, possibilitando, inclusive, livre ação aos sabotadores que cortavam linhas de comunicação e explodiam fábricas. A direção do Banco Francês, com liberdade de ação, financiava a contrarrevolução. Mas, em consequência a essas ações, em meados de abril, a Comuna decidiu não permitir a continuidade das atividades dos sabotadores e passou a proibir a circulação dos jornais monarquistas. Em síntese, a relação, configuração e a existência de uma democracia de novo tipo foram explicitadas pelas iniciativas assumidas pela Comuna:

[...] eleição, não só para os cargos governamentais, como também para os cargos militares, administrativos e judiciários do Estado; mandato imperativo, revogável a qualquer momento pelos eleitores; dissolução do Exército permanente e criação de uma milícia operária; transferência de inúmeras outras tarefas do Estado para a população trabalhadora organizada; salário dos funcionários públicos não superior ao salário médio dos operários (a Comuna foi o "governo mais barato" da história). São essas e outras medidas que configuravam a democracia de novo tipo, que combinava democracia representativa com democracia direta, e representava o início do processo de extinção da burocracia e do próprio aparelho de Estado, como aparelho especial colocado acima da sociedade. (Boito JR., 2001, p. 62)

\subsection{A reação passa à ofensiva e impõe o terror}

A reação do governo de Thiers contra os revolucionários passa a ser desenvolvida com grande violência por um longo período, e deixa claro que seu objetivo é eliminar toda e qualquer tentativa de oposição mais radical. A violência contrarrevolucionária demonstrou que, para a defesa e manutenção da ordem burguesa, estavam dispostos a cometer as maiores atrocidades.

Thiers assinou, em 10 de maio de 1871, o Tratado de paz com Bismarck, através do qual a França "concedeu" à Prússia as províncias de Alsácia e Lorena e se comprometia a pagar cinco bilhões de francos em ouro, na qualidade de "contribuição de guerra"; em contrapartida, seriam libertados 
60 mil soldados franceses, permitindo à reação organizar um efetivo militar de 170 mil. A tropa era bem alimentada, vestida, isolada de contato com o exterior e imposta a rígida disciplina. Isso permitiu a reorganização militar da reação e sua concentração no ataque a Paris.

O fato inédito de que, na mais tremenda guerra dos tempos modernos, o exército vencedor e o exército vencido confraternizem na matança comum do proletariado não representa, como pensa Bismarck, o esmagamento definitivo da nova sociedade que avança, mas o desmoronamento completo da sociedade burguesa. A empresa mais heroica de que é ainda capaz a velha sociedade é a guerra nacional. E fica provado agora que é ela uma pura mistificação dos governos, destinada a retardar a luta de classes, e da qual se prescinde logo que essa luta eclode sob a forma de guerra civil. A dominação de classe já não pode ser disfarçada sob o uniforme nacional; todos os governos nacionais são um só contra o proletariado! (MARX, 1977, p. 215)

No dia 21 de maio foi dado início ao ataque final sobre Paris. Começava, assim, o que ficou conhecido como Semaine sanglant, quando se disputou em violentas batalhas cada palmo de rua e barricada. O proletariado construía uma barricada após outra e as defendia com grande heroísmo. A tomada de posse pelas tropas da reação de cada rua, cada casa, cada barricada, só foi possível depois de violenta luta. Em grande inferioridade, os rebeldes não se rendiam. Resistiram valentemente, em uma batalha desigual, tombando crivados pelas balas inimigas. As tropas francesas encontraram maior resistência e heroísmo nos bairros operários, inclusive defendidos com a participação de grande número de mulheres e jovens.

No dia 27 de maio, as tropas a serviço do governo de Thiers ocuparam a barricada operária de Belleville. Os aproximadamente 200 revolucionários que ainda lutavam no cemitério de Pére Lachaise foram cercados e implacavelmente aniquilados. Ao finalizar o dia, um pequeno grupo de sobreviventes foi sitiado e fuzilado aos pés da parede do cemitério.

A última barricada operária a resistir foi a da rue de Ramponneau. Essa última trincheira da liberdade caiu em poder das tropas de Thiers no dia 28 de maio. Mas a vitória definitiva só se consumaria no dia 29, quando foram disparados os últimos tiros. O Forte de Vincennes foi ocupado e nove revolucionários fuzilados.

As tropas militarmente vitoriosas começaram a mais violenta repressão e instalaram o terror não só contra os communards, mas contra a população. A simples suspeita e a delação de algum funcionário representava condenação à 
morte. A fúria ensandecida transformou-se em alavanca e justificativa para as execuções sumárias. Líderes da Insurreição eram atados, arrastados pelas ruas da cidade, golpeados, insultados e assassinados. Trinta mil revolucionários foram sumariamente fuzilados e mais de 40 mil, jogados nas prisões ou deportados para diversas colônias, condenados a trabalhos forçados; um número expressivo desses, vítimas de enfermidades e de duras condições de sobrevivência foram levados à morte.

A vitória da contrarrevolução monarquista e burguesa levou Thiers, um historiador alheio à dinâmica da luta de classes, a proferir, de forma arrogante e histórica, a célebre frase: "O socialismo está acabado por muito tempo" (LissagaraY, 1991, p. 292). Ao contrário, o socialismo e o comunismo, derrotados militar e momentaneamente na França, logo após se afirmaram em outros países do continente, iniciando com a Revolução Russa a Era das Revoluções Socialistas. Inclusive, mais recentemente, as débâcles da URSS e do Leste Europeu não significaram a inviabilidade de construção dessa nova sociedade. Aliás, essas experiências, juntamente com a da Comuna de Paris de 1871, constituem um manancial inesgotável que, submetido a análises rigorosas de seus erros e acertos, nos permite extrair importantes ensinamentos e reafirmar a existência de possibilidades reais de superação do militarismo e da barbárie capitalista.

\section{INTERNACIONALISMO}

As revoluções burguesas, principalmente depois de 1789, contra a ordem monarquista também trouxeram consigo o slogan universalista de liberdade, igualdade e fraternidade. Estes princípios formais, elaborados pelos pensadores contratualistas, e o iluminismo (que todos os homens têm o direito de resistir contra os regimes opressores) contribuíram para legitimar as insurreições e revoluções contra os regimes monarquistas baseados em privilégios e discriminações. Assim, as transformações em um determinado país repercutiam imediatamente em outros, seja pela reação das forças de conservação da ordem que tentavam manter seus privilégios de classe; seja pela necessidade de que tinham os regimes burgueses emergentes de se defenderem. Isso fez com que as mudanças na Europa do século XIX tivessem impactos decisivos além das fronteiras geográficas e da repartição política e territorial entre as monarquias.

Resulta especialmente significativo, no que diz respeito aos aspectos internacionais das revoluções posteriores a 1789, que a Revolução 
Francesa se converteu em algo mais que uma simples revolta contra problemas especificamente franceses: as reivindicações e os slogans dos revolucionários da França, como liberdade, fraternidade e igualdade, podiam ser aplicados de maneira óbvia a qualquer país e século. De fato, alguns conceitos e ideologias que surgiram da França revolucionária, como democracia e socialismo, se desenvolveram de maneira específica como movimentos conscientes internacionais por parte de intelectuais revolucionários como Karl Marx. Também convém assinalar que os avanços tecnológicos na imprensa e comunicações fizeram possível que as ideias se propagassem com rapidez, não só dentro de um país determinado, mas também além de suas fronteiras [...]. Cada vez era mais evidente aos revolucionários e conservadores que a revolução, do mesmo modo que o desenvolvimento econômico, estava se convertendo com grande velocidade em um fenômeno interrelacionado em escala global. (TodD, 2000, p. 112)

\subsection{A ideia de nação e o internacionalismo burguês}

A concepção burguesa - que pressupõe um conteúdo genérico de liberdade em abstrato, de igualdade em abstrato, de fraternidade em abstrato, ou seja, de direitos universais abstratos e de homem abstrato necessita e constrói conjuntamente a ideia abstrata de povo, independente de suas origens étnicas e classes sociais, como sendo os habitantes de um determinado espaço geográfico e político, denominado Nação.

A ideologia burguesa, ao elaborar ideias de igualdade e direitos universais em abstrato, busca eliminar as contradições e as desigualdades reais - entre as classes sociais e uniformizar a sociedade. Assim, no esforço de neutralizar a ação coletiva do proletariado e impedir sua identidade de classe, apresenta o Povo-Nação - todos aqueles que habitam o mesmo espaço político e geográfico, possuem as mesmas "tradições" e "história", falam o mesmo idioma, têm a mesma cor da pele etc. -, como a identidade coletiva. Mas, a destruição da hegemonia da nobreza, as transformações políticas, o desenvolvimento das forças produtivas e "a internacionalização da produção capitalista fazem [...] com que a burguesia se torne uma burguesia internacional e o proletariado um proletariado internacional. Há, portanto, uma burguesia e um proletariado europeus (e mundial), não vários" (PALÁcios, 1995, p. 27).

Na realidade, o Povo-Nação, a nacionalidade - ao transformar desiguais em juridicamente iguais - tenta criar identidade de interesses entre operário e capitalista e busca negar o antagonismo engendrado ao nível das relações 
de produção que se manifesta por toda a sociedade. Dessa forma, elimina a divisão da sociedade em classes sociais antagônicas, em luta irreconciliável, assim como a contradição essencial entre capital e trabalho (Costa, 2011).

Ao implantar a coletividade nacional, o Estado burguês define todos os agentes da produção, produtores diretos ou proprietários, como iguais, tal igualdade consistindo em sua condição comum de habitantes de um mesmo território. [...] Assim, a unificação aparente ou formal dos agentes da produção em Povo-Nação transforma os produtores diretos em indivíduos: neutraliza sua tendência ao isolamento. Essa individualização é um obstáculo à luta dos produtores diretos contra os proprietários dos meios de produção que lhes extorquem o sobretrabalho; nessa medida, ela torna possível a renovação contínua desse processo de extorsão. [...] O Estado burguês, ao representar a unidade [...] dos membros das classes sociais antagônicas no Povo-Nação desempenha a função de neutralizar a tendência à formação de comitês de fábrica, sindicatos operários, partidos revolucionários; isto é, de atomizar os produtores diretos, conservandoos num estado de massa (individualismo, concorrência no mercado de trabalho) e impedindo sua constituição em classe social. (PALÁcios, 1995, p. 26)

A Comuna de Paris de 1871 desmistificou o discurso burguês do Estado-Nação, do nacionalismo burguês e revelou o caráter internacional da aristocracia e da burguesia e, consequentemente, das classes e da luta de classes. As classes proprietárias não opuseram resistência significativa à ocupação da França - e de Paris - pelas tropas prussianas inimigas, mas, devido à rebeldia do proletariado, elas se apressaram nas negociações com os monarquistas prussianos.

Thiers expôs, com muita clareza, aos componentes de seu governo e à Assembleia Nacional que era necessário aprovar imediatamente as condições de paz com Bismark, sem perda de tempo e sem conceder as honras de um debate parlamentar, pois essa era a única circunstância sob a qual a Prússia permitiria iniciar a guerra contra a República e contra Paris, que naquele momento era seu baluarte. Na realidade, Thiers afirmava que a contrarrevolução francesa e europeia, em aliança contra o proletariado, não tinha tempo a perder.

As classes proprietárias se submeteram às imposições prussianas e, com a garantia de não intervenção (e inclusive de apoio) do Exército inimigo, elas organizaram e concentraram sua violência e poder de destruição contra seus "cidadãos", contra a Comuna. 
O fato inédito de que, na mais tremenda guerra dos tempos modernos, o exército vencedor e o exército vencido confraternizem na matança comum do proletariado não representa, como pensa Bismarck, o esmagamento definitivo da nova sociedade que avança, mas o desmoronamento completo da sociedade burguesa. A empresa mais heroica de que ainda é capaz a velha sociedade é a guerra nacional. E fica provado agora que é ela uma pura mistificação dos governos, destinada a retardar a luta de classes, e da qual se prescinde logo que essa luta eclode sob a forma de guerra civil. A dominação de classe já não pode ser disfarçada sob o uniforme nacional; todos os governos nacionais são um só contra o proletariado! (MARX, 1977, p. 215)

\subsection{0 internacionalismo proletário}

Explicitando as contradições entre o discurso ideológico mistificador e a prática agressiva e imperialista em que se afirmava o nacionalismo burguês, Marx e Engels (em contraposição) revelaram - já em 1848, no Manifesto do Partido Comunista - o conteúdo internacional das relações capitalistasburguesas e das classes sociais. Este exteriorizava o caráter internacional da dominação e exploração de classe (nacional somente enquanto forma de manifestação) e, consequentemente, o caráter internacional das classes e da luta da classe operária, ou seja, o internacionalismo proletário. Inclusive, esse caráter internacional é exposto no frontispício do Manifesto: ¡Proletários de todo mundo, uni-vos!

Nesse sentido, a Comuna de Paris de 1871 foi a primeira experiência e manifestação do conteúdo internacional das classes, da dominação de classe e da luta entre as classes, pois revelou - com grande nitidez, contundência e violência - a aliança e união das aristocracias e burguesias francesas e prussianas contra o proletariado de Paris.

A Comuna de Paris - ao se posicionar contrária à submissão da França e à entrega de Paris para a dominação prussiana - não o fez movida somente pelo sentimento nacional. Uma série de razões, naquele momento, colocava com grande evidência que a luta de classes não se limitava às fronteiras nacionais, a um só país; ela era internacional, como ficou demonstrado cristalinamente pelas posições assumidas pelo proletariado de Paris e pelas classes proprietárias francesas em aliança com as tropas prussianas de ocupação.

Essa luta do proletariado parisiense contra as aristocracias e as burguesias francesas e prussianas assumiu conteúdo internacional, posto que recebeu solidariedade da classe operária de diferentes países, revelando 
que os problemas das classes dominadas e exploradas não se restringem às fronteiras políticas e geográficas. Compreendeu-se que a opressão de que uma é objeto é a mesma das classes exploradas de outras nações, e que todas são parte dessa sociedade civil mais ampla, a sociedade mundial. Os problemas e as lutas do proletariado francês, então (ficou claro), eram os mesmos que os do proletariado alemão, do proletariado inglês, do proletariado espanhol, e assim sucessivamente. Conclui-se, pois, que os conflitos locais e nacionais, manifestações concretas da luta de classes, tendem a desaparecer com a internacionalização das relações sociais, convertendo-se em conflitos que superam os limites nacionais.

Nesse sentido foi que o proletariado francês obteve o apoio e a solidariedade do movimento operário e socialista de vários países - sobretudo da Associação Internacional dos Trabalhadores, a Internacional - e incorporou inumeráveis socialistas estrangeiros em suas fileiras. Esses, convictos dos princípios do internacionalismo proletário, escolheram vários estrangeiros para posições de direção na Comuna, muitos dos quais morreram nas barricadas em defesa da república universal. Isso porque "a bandeira da Comuna é a bandeira da República mundial” (MARx, 1977, p. 162).

Não obstante, ao largo de sua curta existência de 72 dias, a Comuna de Paris encontrou muitos partidários por toda Europa, pertencentes sobretudo à gente trabalhadora corrente, em geral membros de sindicatos e uma minoria significativa de partidários da Primeira Internacional de Marx. Mandaram mensagens de apoio e organizaram, quando foi possível, reunião pública de solidariedade. A maior dessas manifestações foi realizada no Hyde Park de Londres em 16 de abril de 1871, com 30.000 participantes. Além de que, apesar da derrota da Comuna no mês seguinte, os Communards legaram ao movimento internacional operário os símbolos que ainda perduram: a bandeira vermelha do socialismo e a famosa canção do comunismo, a "Internacional", escrita pelo communard Eugène Pottier. (ToDd, 2000, p. 119)

A Comuna de Paris de 1871 possibilitou aos proletários de Paris e ao proletariado mundial o entendimento de que não só era possível, mas um dever imperativo e um direito lutar pela concretização dos princípios de liberdade, igualdade e fraternidade internacional. Não bastava se limitar, simplesmente, a se apoderar da máquina do Estado (nacional) tal como se apresentava e servir-se dela, mas fazia-se necessário tomar o poder político e construir um novo tipo de Estado que lhes possibilitasse atingir os fins: tornarem-se senhores de seu próprio destino. 


\section{AS MULHERES REVOLUCIONÁRIAS}

Naquele momento em que as mulheres, mesmo que ainda de forma insuficiente, passaram a desempenhar importantes cargos em diversos níveis - como professoras, cientistas, parlamentares, ministras etc. - e a avançar rumo a ocupação de significativo espaço público, é oportuno destacar a participação das revolucionárias, denominadas pejorativamente pelas forças reacionárias e aristocrático-burguesas de les pétroleuses, ou seja, as incendiárias.

A presença e a participação feminina nas lutas políticas e revolucionárias na França e em outros países foi uma constante; inclusive, o símbolo da República francesa é representado por uma mulher. Contudo, em que pese a destacada participação das mulheres nos principais acontecimentos de nossa história, principalmente a partir da denominada história moderna, até algumas décadas atrás, o envolvimento feminino nas lutas políticas revolucionárias não era estudado.

As mulheres estiveram presentes, mas relegadas e marginalizadas. Essa realidade vem sendo mudada nos últimos decênios pelo esforço destacado das feministas. Essas ousaram investigar e comprovaram que (em cerca de $50 \%$ da população, possivelmente com pequenas diferenças em um ou outro período) estiveram participando dos principais fatos em toda a história da humanidade. O destaque fica por conta das trabalhadoras que desafiando os preconceitos e os limites culturais, inclusive contra homens revolucionários - conquistaram seus direitos, não somente como parte integrante da parcela social majoritária, explorada e oprimida, mas também seus direitos específicos enquanto mulheres.

Em todas as revoluções burguesas e proletárias dos séculos XVIII, XIX e XX,

as mulheres com estudos utilizaram as oportunidades que se lhes ofereceram de defender reivindicações sociais, econômicas e políticas radicais, sobretudo aquelas destinadas a transformar o lugar que ocupam as mulheres na família e na economia, em concreto mediante a exigência de direitos e igualdade legais. Sem dúvida, as mulheres da classe baixa também participaram, sobretudo quando os problemas econômicos ameaçavam seu nível de vida e o de suas famílias. Com frequência estas mulheres conectaram estas questões com as lutas pelo poder e as mudanças políticas radicais que tinham lugar e fizeram pleno uso da oportunidade de pressionar a favor de reformas legais e constitucionais. [...] Sem dúvida, em linhas gerais, os homens revolucionários não parece 
que hajam tido muito em conta os direitos da mulher [...] muitos homens temiam, ao que parece, que as mulheres participassem em atividades políticas. Como consequência, os políticos e historiadores homens ignoraram as mulheres revolucionárias ou as pintaram como amazonas e feras, enquanto que muitos homens radicais têm-se mostrado, às vezes, pouco dispostos a respaldar os direitos da mulher, por receio de parecerem insensatos aos olhos dos demais homens. (ToDD, 2000, p. 128)

\subsection{As mulheres na Revolução de 1789}

Já no ano de 1789 e posteriores, as mulheres participaram de forma destacada nas lutas revolucionárias. Como um dos setores mais sensíveis às consequências das crises, elas assumiram papel de relevo nas mobilizações contra a escassez, a fome, a irregularidade no abastecimento, mas não ficaram somente nessas lutas; começaram a formular e a apresentar suas reivindicações específicas, de forma cada vez mais enfática. Criaram associações destinadas a exigir a defesa dos direitos das mulheres, como, por exemplo, a Sociedade de Mulheres Republicanas Revolucionárias, ${ }^{1}$ fundada em fevereiro de 1793, por Claire Lacombe ${ }^{2}$ e Pauline Léon, ${ }^{3}$ responsável por diversas conquistas revolucionário-populares. Algumas feministas conseguiram avultar-se na defesa de seus direitos, colocando-os como parte das plataformas políticas mais gerais. Dentre essas se sobressaíram: MarieJeanne Roland, conhecida como "Manon" Roland, ${ }^{4}$ discípula de Rousseau e célebre como a filósofa republicana; a holandesa Etta Palm d'Aelders; ${ }^{5}$ Olympe de Gouges, ${ }^{6}$ que redigiu uma Declaração dos Direitos da Mulher; Tréroigne de Méricourt, ${ }^{7}$ que se destacou no grupo Amigos da Constituição em 1790. Importante anotar que a participação das mulheres naquele momento foi identificada, pelo próprio caráter e pelo conteúdo de classe, com a perspectiva burguesa e que elas não avançaram em suas reivindicações específicas, o que só ocorreria posteriormente.

\subsection{As mulheres na Primavera dos Povos em 1848}

Em geral, a participação feminina nas revoluções de 1848, quando da Primavera dos Povos, manifestou um conteúdo um pouco diferente da fase anterior, pois foi relevante a presença das trabalhadoras e o surgimento das ideias socialistas e comunistas que defendiam a igualdade para as mulheres e as associavam com a emancipação de classe, com a superação da ordem existente. 
A Revolução de 1848, na França, principalmente em Paris, a exemplo de outros períodos revolucionários, sobrelevou-se como o momento em que aconteceu o maior número de manifestações proletárias, nas quais as mulheres se destacaram por atuar de forma independente na organização de greves e associações gremiais. Elas reivindicaram que o Plano Nacional de Trabalho não fosse restrito a minorar apenas as consequências do desemprego masculino, ou seja, excludente às mulheres. Aliás, conseguiram que representantes dos grêmios de mulheres fizessem parte da Comissão Luxemburgo, responsável por analisar e apresentar ao Governo Provisório, sugestões relativas aos salários e às condições de vida dos trabalhadores.

Entre as organizações específicas fundadas nesse período, sobressaíram-se: as Vésuviennes que, ao lutar pelas reivindicações femininas, organizavam grupos de mulheres para treinamentos com conteúdo militar; o Clube para a Emancipação das Mulheres; a União das Mulheres e a Associação Fraternal de Democratas de Ambos os Sexos que reivindicavam a igualdade de direitos para as mulheres, o direito ao divórcio e de voto. Registrou-se, também, que muitas mulheres assistiram às reuniões da Sociedade Republicana Central, dirigida por Blanqui, e que, em algumas cidades das províncias, surgiram clubes femininos (ToDd, 2000, p. 135).

Os defensores dos direitos da mulher também imprimiram milhares de cartazes, boletins e conclamações, além de fundar revistas e jornais; o mais importante deles, La Voix des Femmes (A Voz das Mulheres), defendia o divórcio e creches para os filhos das mulheres trabalhadoras. Fora de Paris, seus esforços tendiam a limitar-se a exortar a seus maridos para que passassem à ação [...], sem dúvida, a medida que o processo de politização característico das revoluções de 1848 se estendia, a participação política das mulheres tendia a aumentar. Algumas lutaram nas barricadas durante a revolução de fevereiro, mas foram muitas mais as que participaram na acentuada luta de rua de junho de 1848. As mulheres de Paris lutaram com tanta decisão como os homens e constituíram uma pequena porcentagem do total de mortos, feridos ou feitos prisioneiros. Ainda que algumas se limitassem a carregar e limpar as armas, outras dirigiram grupos de combate integrados só por homens. A atividade política das mulheres se restringiu depois que se reprimiu o levante dos "dias de junho", mas muitas haviam aumentado sua consciência social e política. (TodD, 2000, p. 135)

Muitas das ativistas femininas, ou melhor, feministas, lutaram não só nos acontecimentos da Revolução de 1848 na França, mas tiveram papel político importante nas lutas feministas posteriores, entre as quais 
se destacam: Eugénie Niboyet, responsável pela publicação do periódico parisiense $\mathrm{A}$ Voz das Mulheres, dedicado à defesa dos direitos específicos das mulheres; Jeanne Déroin, ${ }^{8}$ fundadora do Clube para a Emancipação das Mulheres; Joséphine Courbois, conhecida como a rainha das barricadas, por sua atuação relevante nas barricadas em Lyón e, depois em 1871, em continuidade a sua militância, lutou nas barricadas da Comuna de Paris; Amadine Lucile Aurore Dudevant, conhecida como George Sand, ${ }^{9}$ intelectual e escritora conhecida por suas ideias republicanas e revolucionárias.

Em outros países da Europa, a presença e participação feminina nas lutas revolucionárias de 1848 não alcançaram o nível e a intensidade que teve na França.

No Império Austro-Húngaro, em Viena e Praga, as mulheres (mesmo que não haja registros de que apresentassem reivindicações específicas) se reuniam para tratar de assuntos políticos e publicar periódicos. Mas há registros de que em Praga, em junho de 1848, participaram das lutas, e em Viena, em outubro, auxiliaram na construção de barricadas. Na Hungria se chegou a formar dois regimentos femininos e algumas mulheres, disfarçadas de homens, alistaram-se nas tropas; até mesmo há o caso de duas terem atingido o posto de capitão antes de serem descobertas. A existência de organizações femininas se restringiu praticamente a Praga e Viena onde se dedicavam a apoiar os refugiados políticos e insurgentes prisioneiros. $\mathrm{O}$ Clube das Mulheres Eslavas, organizado em Praga, se dedicava à educação das mulheres em sua língua pátria.

Nos estados alemães, na cidade têxtil de Elberfeld, as mulheres participaram, no 31 de março de 1848, de uma manifestação em apoio aos trabalhadores e pela unificação da Alemanha, quando propuseram que se usasse somente a roupa confeccionada no país. Em outras localidades e eventos, a participação se limitou a atividades de apoio. Os homens em seus clubes políticos, inclusive os burgueses radicais, com exceção dos socialistas e comunistas, não permitiam a participação feminina. Em Berlim, o pequeno Congresso dos Trabalhadores, que coligava 31 organizações, apoiava a reivindicação de igualdade para as mulheres. Registrou-se, também, a existência do Clube Democrático de Mulheres, no qual se destacaram as feministas Matilde Franziska Anneke ${ }^{10}$ e Luise Otto-Peters, responsáveis pela publicação de periódicos.

Nos estados italianos, antes de 1848, em que pese certa presença das mulheres e de suas ideias nacionalistas e liberais, sua participação se limitou (com algumas poucas exceções) a apoiar as atividades revolucionárias dos homens. Em geral, as mulheres italianas, naquele período, não foram além 
do apoio aos esposos e familiares. Sobressaiu-se nos estados italianos a brasileira Anita Garibaldi, considerada a verdadeira heroina italiana, por sua participação ao lado de Garibaldi, seu esposo, nas lutas pela unificação da Itália.

\subsection{As mulheres na Comuna de Paris}

De todas essas lutas revolucionárias em que as mulheres tiveram efetiva participação política, o grande destaque deu-se com a Comuna de Paris, seja por seu conteúdo político ou pelo número e intensidade.

Em 1871, os trabalhadores suportavam precárias condições de vida, e as trabalhadoras - em que pese a participação das mulheres nas jornadas revolucionárias em quase um século de luta de classes - padeciam de dupla exploração e discriminação (enquanto mulheres e trabalhadoras) além de estarem excluídas de direitos políticos básicos, como o direito ao voto. Um exemplo das discriminações às quais estavam submetidas as mulheres é explicitado pelo código civil francês ${ }^{11}$ (modelo de código civil burguês e seguido em diferentes países: " um dos documentos mais reacionários no que diz respeito à questão da mulher; despojava-a de todo e qualquer direito, submetendo-a inteiramente ao pai ou ao marido; não reconhecia a união de fato e só reconhecia aos filhos do casamento oficial" (MARTINs, 1991, p. 47-48). Para muitas mulheres, a Comuna se apresentou não só como uma possibilidade de conquistar uma República social, mas de conquistar uma República social com igualdade de direitos para as mulheres.

No dia 18 de março de 1871, considerado o dia do deflagrar da Comuna, foram as mulheres as primeiras a dar o alarme, revelando a intenção das tropas de retirar os canhões das colinas de Montmartre e desarmar Paris, a mando do governo de Thiers. Puseram-se diante das tropas governamentais e impediram, com seus corpos, que os canhões fossem retirados e, assim, incitaram a reação do proletariado e da Guarda Nacional à defesa de Paris.

Em concreto, as mulheres trabalharam em fábricas de armas e munições, fizeram uniformes e dotaram de pessoal aos hospitais improvisados, além de ajudar a construir barricadas. Muitas delas foram destinadas aos batalhões da Guarda Nacional como cantinières, onde se encarregavam de proporcionar alimentos e bebida aos soldados das barricadas, além dos primeiros auxílios básicos. Na teoria, eram quatro as cantinières destinadas a cada batalhão, mas na prática ocorria ser muito mais. Por outra parte, abundantes dados mostram que muitas mulheres recolheram as armas de homens mortos ou feridos e lutaram com grande 
determinação e valentia. Também houve um batalhão composto por 120 mulheres da Guarda Nacional que lutou com valentia nas barricadas durante a última semana da Comuna. Obrigadas a retirar-se da barricada da Place Blanche, se transladaram à Place Pigalle e lutaram até que as cercaram. Algumas escaparam ao Boulevard Magenta, onde todas morreram na luta final. (ToDd, 2000, p. 140)

As mulheres desenvolveram uma série de atividades, mais destacadamente, as destinadas à assistência aos feridos e enfermos, à educação em geral e ao abastecimento. Mesmo que não houvesse movimentos e organizações feministas, como conhecemos hoje, e não tivesse sido elaborado um programa só com reivindicações específicas, as revolucionárias criaram cooperativas de trabalhadores e sindicatos específicos para as mulheres. Participaram ativamente de clubes políticos que lutavam pela igualdade de direitos, como, por exemplo, o Clube dos Proletários e o Clube dos Livrepensadores. Criaram organizações próprias, como o Comitê de Mulheres para a Vigilância, o Clube da Revolução Social e o Clube da Revolução, mas o que conseguiu sobrelevar-se entre eles foi a União de Mulheres para a Defesa de Paris e a Ajuda aos feridos, fundada por membros da Internacional, influenciados pelas ideias de Marx. Também, publicaram-se periódicos destinados especialmente às mulheres: Le Journal des Citoyennes de la Comuna (Jornal das Cidadãs da Comuna) e La Sociale (A Sociedade).

As revolucionárias na Comuna adquiriram importância não só como lutadoras das causas sociais, mas como feministas; pertenciam à classe operária (ou aos setores radicais dos setores médios), identificada com as lutas pela conquista de uma República social com igualdade de direitos. Nesse período, quem ficou mais conhecida foi a ativista socialista Louise Michel, ${ }^{12}$ fundadora da União de Mulheres para a Defesa de París e de Ajuda aos Feridos e membro da I Internacional. Destacaram-se ainda: Elizabeth Dmitrieff, ${ }^{13}$ militante socialista e feminista; André Léo, ${ }^{14}$ responsável pela publicação do periódico La Sociale; Beatriz Excoffon, ${ }^{15}$ Sophie Poirier y Anna Jaclard, militantes do Comitê de Mulheres para a Vigilância; Marie-Catherine Rigissart, que comandou um batalhão de mulheres; Adélaide Valentin, que chegou ao posto de coronel, e Louise Neckebecker, a capitão de companhia; Nathalie Lemel, Aline Jacquier, Marcelle Tinayre, Otavine Tardif y Blanche Lefebvre, fundadoras da União de Mulheres, sendo que a última foi executada sumariamente pelas tropas da reação; e Joséphine Courbois, que havia lutado em 1848 nas barricadas de Lyón, onde era conhecida como a rainha 
das barricadas. Necessário ainda citar Jeanne Hachette, Victorine Louvert, Marguerite Lachaise, Josephine Marchais, Leontine Suétens e Natalie Lemel.

Após a derrota militar da Comuna de Paris de 1871, as forças conservadoras e reacionárias - na impossibilidade de eliminar esse exemplo heroíco que demonstrou a possibilidade de destruição da ordem burguesa disseminaram uma grande campanha de calúnias contra o proletariado, as mulheres revolucionárias, os socialistas, os comunistas e em particular contra a I Internacional.

Algumas fontes fazem referência às incendiárias, as pétroleuses, que atearam fogo aos edifícios públicos durante a Semaine Sanglante final da Comuna. Essas histórias parecem ser fruto do alarmismo antifeminista de inspiração governamental e a maoria dos correspondentes estrangeiros presentes não acreditaram. Não obstante, as tropas governamentais executaram de maneira sumária a centenas de mulheres, e inclusive lhes batendo até a morte, porque eram suspeitas de ser pétroleuses. Contudo, apesar do fato de que mais tarde se acusou a muitas mais mulheres de ser incendiárias, os conselheiros de guerra não encontraram nenhuma culpável desse delito. Sem dúvida, há provas que indicam que, durante os últimos dias, as mulheres aguentaram mais tempo detrás das barricadas que os homens. No total, foram submetidas 1.051 mulheres a conselhos de guerra, realizados entre agosto de 1871 e janeiro de 1873: oito foram sentenciadas a morte; nove a trabalhos forçados e 36 a serem deportadas às colônias penitenciárias. (ToDD, 2000, p. 140-141)

A Comuna de Paris e a destacada participação feminina em atividades consideradas até então como masculinas reafirmaram a força revolucionária da mulher, já desenhada a partir da revolução de 1789, e que se transformou em uma onda histórica mundial indestrutível. As mulheres, a partir da Comuna de Paris, passaram a contribuir com grande parte da força que colocou em movimento a máquina da revolução proletária, indicando que elas não mais deixariam a cena da luta dos explorados e oprimidos por uma nova sociedade de progresso social e de liberdade.

\section{A atualidade da Comuna de Paris}

Completaram-se, em 2011, 140 anos transcorridos desde a Comuna de Paris de 1871, importante acontecimento na história das lutas sociais, e situado entre o que se denomina a "era das revoluções burguesas" e a "era das revoluções proletárias". Sintomaticamente, a Comuna de Paris foi 
esquecida pela historiografia "oficial" (ou "oficiosa") e, inclusive, por parcela da esquerda. Os motivos para esse "desconhecimento" são diversificados e definidos, quase sempre, a partir das posições políticas e ideológicas assumidas por cada um dos diferentes segmentos ou classe social.

Nos últimos anos, o termo revolução tem sido muito utilizado, quase sempre de forma confusa, para se referir a mudanças nos diferentes campos da atividade humana: revolução na moda, revolução nas artes, revolução tecnológica, revolução no mundo da informação. Essa utilização, aproveitando a boa receptividade social ao novo e diferente, tenta demarcar um espaço de superação do existente, já considerado velho, por algo que apresenta características "novas" e mais "avançadas". Mas em parte, essa utilização da denominação não corresponde ao conteúdo a que se refere, ao que se quer expressar; o termo revolução, relacionado às mudanças sociais e políticas profundas, quase não é utilizado, salvo em ocasiões excepcionais.

A maioria dos estudos históricos e os livros publicados nos dias atuais preferem se ocupar, quase que exclusivamente, de fatos secundários, do cotidiano, do pitoresco e curioso, de características comportamentais de nobres e aristocratas, dos grandes feitos dos líderes e dirigentes pertencentes às classes dominantes. Assim, a história é interpretada como uma narração dos costumes sociais, identificada como sendo uma somatória de fatos isolados e curiosos, e é, em grande parte, associada à picardia.

$\mathrm{Na}$ atualidade, tenta-se formar e consolidar, entre parcelas significativas da população, a opinião e a compreensão de que o estudo da História não tem sentido. Argumenta-se, neste início de milênio (de anúncio do Terceiro Milênio), que ser moderno, ou mesmo pós-moderno significa identificar-se com o individualismo e o irracionalismo metodológicos. Mistificadores propagandeiam a ideia de que a História não tem estatuto científico e, ao estudá-la, devemos restringir-nos à leitura sobre os aspectos e comportamentos individuais e subjetivos, enfim, a fatos pitorescos. Esse tipo de concepção tenta nos impor a compreensão de que chegamos ao "fim da história", à primazia do individualismo e do subjetivismo. Ironicamente apregoam aos "quatro ventos" que a barbárie liberal, recém-batizada de neoliberalismo, é o primado da democracia, da liberdade individual e é o objetivo e o fim último do desenvolvimento social. Afirmam não haver alternativas que se contraponham ao mercado, ao reinado da mercadoria. Os antagonismos sociais reais, a defesa de um ideal igualitário - que move as sociedades - estão fracassados. Veja o Leste Europeu, a ex-URSS e a crise e decadência das experiências socialistas (Costa, 2011, p. 14). 
Embora significativa parcela do que estudamos e que nos é ensinado tente evitar referir-se aos fatos revolucionários que cunharam a história da humanidade, não é possível estudar e referir-se à História Moderna e Contemporânea sem deter-se nas grandes revoluções burguesas e popular-proletárias que marcaram os séculos XVIII, XIX e XX. Inicia-se com a Revolução burguesa Francesa (deflagrada em 1789), passando pelas Revoluções de 1848 (em diferentes países europeus) ${ }^{16}$ e pela Comuna de Paris - quando pela primeira vez na história, as classes exploradas e oprimidas assumiram o poder político e tentaram uma nova forma de organização social - até as revoluções que iniciam a "era das revoluções proletárias", nas primeiras décadas do século XX, entre as quais se destaca as Revoluções Russa, Chinesa e Cubana.

Não há como negar o fato de que, nos três últimos séculos, a história da humanidade foi abalizada por grandes agitações sociais e políticas de conteúdo revolucionário, impactando e transformando a vida de milhões e milhões de pessoas (nos diversos continentes), envolvidas, direta ou indiretamente, seja nas revoluções burguesas, seja nas revoluções populares e proletárias, ou nas lutas anticoloniais e anti-imperialistas. Concordando ou não, todos nós, estamos de certa forma marcados, com intensidade e de maneiras diferentes, pelo acentuado processo de revoluções e contrarrevoluções.

Sobre as revoluções populares e proletárias, qual seja a avaliação sobre seus resultados, seus erros e acertos, pode-se afirmar que, do ponto de vista da construção de uma sociedade igualitária e fraterna, ainda são revoluções incompletas; apresentam uma série de problemas, debilidades e passam por acentuadas dificuldades que se acreditam ser momentâneas. Por maiores e por mais incríveis que sejam as conquistas alcançadas pelo desenvolvimento da humanidade, os problemas - ocasionados pela distribuição desigual das riquezas, pela manutenção de relações econômicas e sociais baseadas na exploração e opressão - continuam atuais e se aprofundam de forma contundente e implacável. Essas contradições, com o processo de mundialização ou globalização, são agravadas e generalizadas em grande escala, anunciam e confirmam a continuidade do ciclo das revoluções sociais.

É inevitável que, ao se fazer referência à Revolução social e política, surjam diferentes atitudes e comportamentos. Para uns, que a veem como o caminho para superação da velha sociedade, desperta simpatia, admiração e apoio. Para outros, para a minoria que se beneficia dos privilégios impostos pela velha ordem, é tratada com horror e ódio. Uns, entendem que é possível, através de uma revolução social e política, construir um novo tipo de sociedade, lutar por condições de vida menos desiguais, mais 
democráticas, que se limitem os privilégios e haja maior igualdade de direitos econômicos, sociais e políticos. Portanto, esses se envolvem de forma mais ou menos apaixonada no processo revolucionário. Outros compreendem que a vitória das forças revolucionárias significa a redução ou o fim de seus privilégios, portanto tentam impedir o triunfo da nova ordem, somam-se à contrarrevolução.

Aliás, hoje, diferentes setores sociais e forças políticas - na intenção de repudiar o conteúdo revolucionário das lutas pelas conquistas de direitos sociais e políticos pelos trabalhadores e negar, em parte ou na totalidade, aspectos irrefutáveis do passado revolucionário da sociedade e de seu país tentam construir uma visão mistificada de sua história. Assim, em um passo de mágica, as contradições de classes "desaparecem", a secular divisão política entre esquerdas e direitas é substituída pelo pensamento que se pretende "único", os antagonismos sociais reais são substituídos por uma "identidade de interesses", por um "interesse comum". Divulga-se, através de meios de comunicação monopolizados, que só são democratas aqueles que acatam e assumem as posições e a defesa dos interesses econômicos e políticos expressos pela elite dominante e dirigente. Tudo é consenso, negociações e pactos, a não ser isso, é "totalitarismo", é a catástrofe, estaremos condenados ao "inferno".

Acreditamos ser importante sublinhar que as revoluções não são fatos provocados por alguns poucos líderes, "mal" ou "bem" intencionados, pela vontade "soberana" de um rei ou imperador, pois assim estaríamos deixando de lado a História real e construindo uma interpretação parcial, equivocada e, não raramente, fantasiosa.

Necessário evidenciar que a violência existente nos processos revolucionários não é decorrente, em um primeiro momento, de iniciativa das forças revolucionárias, mas uma reação à violência contrarrevolucionária das elites dominantes que tentam, por todos os meios possíveis, manter seus privilégios. Destacamos, ainda, que é um equívoco associar revolução com pobreza e opressão. As precárias condições de vida impostas às classes populares não são responsáveis, sozinhas, pelo aprofundamento do sentimento de revolta e da tomada de consciência de seus reais interesses sociais, mas do misticismo, da desmoralização e da apatia; se assim fosse a história da humanidade seria toda ela repleta de intermináveis revoluções (ToDD, 2000, p. 12).

Como visto, as revoluções não surgem artificialmente, como resultado dos desejos de vinganças e ciúmes. Germinam a partir das modificações econômicas, sociais, políticas, culturais que evidenciam os equívocos, 
as aberrações inerentes ao próprio desenvolvimento das sociedades; e eclodem quando a situação se torna insustentável e uma parte significativa da população se dispõe a lutar e tentar transformar a ordem vigente. Ensinamentos testados novamente, nos dias atuais, pelo proletariado e por diferentes segmentos populares nas praças e ruas, entre outros, da Grécia, Espanha, Portugal, Itália. Estamos vivenciando um ressurgir das "barricadas" communards?

The Paris Commune of 1871 AND the ACtuality of its InTERnationalism

Abstract: The 1871 Paris Commune was the first experience of proletarian government in the history. Even though it happened 140 years ago, it is still relevant. Studying it together with other revolutions can contribute to reveal misconceptions about the end of history. The experience of the Paris Commune makes possible for proletariat understand that struggle for the ideals of liberty, equality and fraternity is not just possible, but it is an obligation and a fundamental right. These ideals continue to be present and are the sap which will lead to the building of a new society.

Key WoRds: Paris Commune, class struggle, revolution, power of the proletariat, feminism.

\section{NOTAS}

1 A SMRR "foi o primeiro grupo político de defesa de interesses específicos de mulheres que se criou na Europa. Fundado por uma atriz e uma fabricante de chocolates, estava vinculado à ala esquerda dos enragés, lutava pelos interesses dos trabalhadores pobres e a maioria de seus membros eram mulheres de trabalhadores pobres. Essas républicaines-révolutionnaires apoiavam os montagnards em sua luta política com os girondinos e fundiam os interesses dos radicais de classe média com aqueles dos pobres de Paris" (TodD, 2000, p. 132).

2 Claire Lacombe foi atriz e depois da proibição da SMRR, por suas posições identificadas como burguesas, foi presa quando da ascensão dos jacobinos ao poder, sendo libertada em agosto de 1795.

3 Pauline Léon, fabricante de chocolate foi presa junto com Claire; logo depois da proibição da SMRR, foi libertada em agosto de 1794, um ano antes de Claire.

4 "Manon" Roland contribuiu na elaboração da política girondina e foi executada em novembro de 1793, quando do ascenso ao poder dos jacobinos.

5 Etta Palm d'Aelders participou de forma relevante da campanha em defesa dos direitos das mulheres, dando destaque à igualdade na educação e no emprego.

6 Olympe de Gouges, como defensora radical dos direitos das mulheres, foi destacada militante revolucionária e morreu guilhotinada em 1793. 
Sua Declaração dos Direitos da Mulher é uma complementação - ou uma contraposição (?) - à Declaração dos Direitos do Homem que não contemplou ou explicitou os direitos das mulheres.

7 Théroigne de Méricourt teve uma atuação vultosa na defesa dos princípios revolucionários e dos direitos das mulheres, defendendo, inclusive, a formação de um batalhão só de mulheres armadas.

8 Jeanne Déroin foi costureira de profissão e militante de esquerda. "Quando Jeanne Déroin propôs apresentar-se como candidata democrata nas eleições de maio de 1849, P.-J. Proudhon a declarou não apta porque os órgãos que as mulheres possuem para alimentar aos bebês não as fazem apropriadas para o voto; ela respondeu pedindo-lhe para mostrar o órgão masculino que lhe facultava para o voto. Foi obrigada a fugir para a Inglaterra em 1851, depois do golpe de Luís Napoleão. Continuou sendo uma feminista ativa até sua morte com a idade de 89 anos" (Todd, op. cit., p. 138-139).

9 George Sand foi "influenciada pelo socialismo de Saint-Simon; era uma republicana acérrima e partidária das barricadas e da revolução. Foi a intelectual mais conhecida de sua época, e muitos de seus 109 livros refletem suas ideias humanitárias. Ao princípio se associou com Armand Barbés, o líder radical do Clube da Revolução, mas em seguida se converteu em conselheira de Alexandre Ledru-Rollin, ministro do Interior do novo governo revolucionário, quem editava os Boletines de la República que contribuíram para propagandear o republicanismo radical nas províncias" (Ibidem).

10 Matilde Franzizka Anneke foi a feminista que mais se destacou nos Estados Alemães. Iniciou sua atuação política como radical e aderiu ao comunismo. Depois do fracasso da Revolução Alemã de 1848 foi obrigada a fugir para os Estados Unidos da América, onde continuou na luta feminista em defesa dos direitos das mulheres (Ibidem).

11 Conhecido também como Código Napoleônico.

12 Louise Michel, militante socialista e fundadora da União de Mulheres, "comandou um batalhão feminino, que enfrentou a reação nas barricadas de Paris. Escapou da morte, foi presa e compareceu diante do Conselho de Guerra em 16/12/1871. Seu julgamento foi exemplo de firmeza e convicção revolucionária. Recusou os advogados a ela designados e apresentou pessoalmente sua defesa, que na verdade, foi a defesa da causa dos communards, ao dizer: "Não quero me defender. Pertenço toda à Revolução Social. Declaro aceitar a responsabilidade por meus atos [...] o que exijo de vós... é o Campo de Satory, onde já tombaram meus irmãos. É preciso separar-me da sociedade, lhes disseram que o fazeis, pois bem! O Comissário da República tem razão. Uma vez que, ao que parece, todo coração que bate por liberdade só tem direito a um pouco de chumbo, exijo minha parte! Se me deixardes viver, não cessarei de clamar vingança e denunciarei, à vingança de meus irmãos, os assassinos da Comissão das Graças." 
Reivindicou morrer no Campo de Satory, o palco do mais odioso tratamento recibido pelos combatentes de Paris. Ali, na noite de 27 para 28 de maio, milhares foram massacrados pelas tropas de Versalhes. Louise não foi condenada à morte, foi deportada para a Nova Caledônia. A anistia votada a 11/7/1880 a beneficiou. Voltou para a França, onde reassumiu, imediatamente, seu posto de combate, em defesa dos oprimidos. Participou e dirigiu várias manifestações de operários e desempregados. Presa várias vezes, foi condenada, em 1883, a seis anos de prisão. Libertada, morreu em 1905. Recebeu inúmeras manifestações de reconhecimento dos trabalhadores de Paris e de toda França. Foi enterrada com o estandarte da Comuna. Louise Michel, mesmo pensando a questão da mulher ainda o fez de forma unilateral, distinguindo-a só como um recurso direto e mecânico do fim da opressão de classe, sem compreender sua dimensão específica. Louise é um símbolo da participação da mulher nas lutas sociais em defesa do progresso e do Socialismo. Não foi só uma lutadora de ações práticas. Professora formada, escreveu várias obras, em que revelou seu pensamento revolucionário, entre elas “Memórias e a Comuna”, em 1898 (Martins, 1991, p. 48).

13 Elizabeth Dmitrieff "filiou-se à Internacional aos 17 anos e se fez amiga de Marx. Chegou a ser uma das sete componentes do comitê executivo da União de Mulheres. Ao final fugiu para a Suíça” (TodD, 2000, p. 142).

14 André Leo, influenciada pelas ideias blanquistas, se dedicava ao jornalismo e, com a derrota da Comuna, se exilou na Suíça.

15 Beatriz Excoffon começou a desenvolver suas atividades políticas a partir do cerco de Paris. Em princípios de abril de 1871 foi uma das organizadoras de uma marcha composta por aproximadamente 800 mulheres que tentaram, sem êxito, impedir que o governo de Thiers atacasse Paris. Com a derrota da Comuna, foi presa e deportada.

16 A Revolução Inglesa, no século XVII, e a Independência dos Estados Unidos da América, no século XVIII, são partes integrantes do processo revolucionário burguês, mas apresentam peculiaridades que fazem com que suas influências, no contexto mundial, sejam particulares; não contribuíram para mudanças diretas e imediatas em outros países.

\section{REFERÊNCIAS}

Boito Jr., A. (Org.). A Comuna de Paris na História. São Paulo: Xamã, 2001.

Costa, S. Comuna de Paris: o proletariado toma o céu de assalto. 2. ed. São Paulo/ Goiânia: Anita Garibaldi/Pontifícia Universidade Católica de Goiás/Fundação Maurício Grabois, 2011.

Lissagaray, H. P-O. História da Comuna de 1871. São Paulo: Ensaio, 1991.

Martins, L. Heroínas no combate: a mulher da Comuna. In: Revista Princípios. São Paulo: Anita Garibaldi, n. 21, maio/jul. 1991. 
Martorano, L. C. Elementos do Estado socialista na Comuna de Paris. In: Boito JR., A. (Org.). A Comuna de Paris na História. São Paulo: Xamã, 2001. p. 67-79.

Marx, K. A guerra civil na França. In: Marx, K.; Engels, F. Textos I. São Paulo: Alfa-Ômega. 1977. v. 3.

Palácios, G. A. A verdade sobre "A ideologia alemã". Goiânia: Cegraf, 1995.

TodD, A. Las revoluciones. 1789-1917. Madrid: Alianza, 2000.

Willard, C. História e vigência da Comuna de Paris. In: Boito Jr., A. (Org.). A Comuna de Paris na História. São Paulo: Xamã, 2001. p. 15-28. 